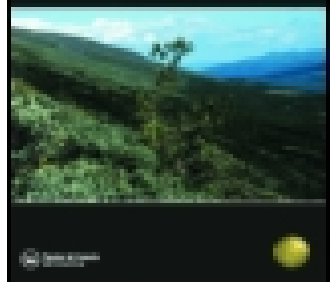

ISSN: 0374-6607 (Print) (Online) Journal homepage: http://www.tandfonline.com/loi/tped18

\title{
Mites And Acarodomatia
}

\section{Professor G. F. Scott-Elliot M.A. B.Sc. F.L.S.}

To cite this article: Professor G. F. Scott-Elliot M.A. B.Sc. F.L.S. (1912) Mites And Acarodomatia, Transactions of the Botanical Society of Edinburgh, 24:1-4, 126-135, DOI: 10.1080/03746601209468951

To link to this article: http://dx.doi.org/10.1080/03746601209468951

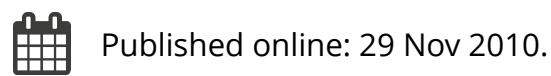

$\sqrt{6}$ Submit your article to this journal $匚$

Џll Article views: 4

Q View related articles ๘ 
Mites and ACarodomatia.

By Professor G. F. Sсотт-Elliot, M.A., B.Sc., F.L.S.

A Swedish botanist, Lundstrom (1), published in 1887now a very long time ago-a classical paper upon mites and their dwelling-places, or, as he called them, acarodomatia. It was then a new subject, and the article, deservedly, attracted a great deal of attention. It is seldom that an original research is not only thorough, exhaustive, and exactly careful in details, but is also both suggestive and extremely interesting.

Quite a number of other botanists began to observe mites and look out for acarodomatia during the next few years. Then, however, followed an interval during which I have not met with any papers on the subject. Since 1903, however, several Italian and other botanists have been studying mites, and the attention of British botanists should be directed to this interesting subject.

The mites are a well-defined and strictly limited class of insects, and yet within the group there is an astonishing variety not only in structure but also in habit of life.

To the mites belong Tetranychus (red spider), Phytoptus (the currant mite), and Tyroglyphus, which are amongst the very worst vegetable parasites known to us. Certain mites are parasites on animals and birds, such as that which forms scabies (or itch) in man. Others live on the feathers of birds. Some live almost entirely in water, and many are saprophytic. Others, again, are active and nimble hunters, true carnivorous animals preying upon all sorts of minute insects.

The particular group of which I wish to speak includes especially two species, Tydeus foliorum and Gamasus spp. I am not a sufficiently good entomologist to be able to say anything about the classification of these mites, and I am not sure if these names still hold. What has interested me most has been their ways of life and their part in the economy of the vegetable world, and it is under these names that they are mentioned in botanical literature.

These particular mites are exceedingly common, as one soon realises when beginning a systematic search for them. 
On the under side of almost any leaf of any of our common trees there are to be found tufts of hairs, often at the angle where a side vein joins the midrib. The small hollows behind the hairs are the homes and shelters of the mites, and have been called acarodomatia. Within the little angle where the side vein branches off, there is often a curiously intricate and complex little cavern reaching up into the tissue, and guarded by a sort of chevaux-de-frise of special trichomes.

I have tried to draw sections of these little caves, but gave up the attempt in despair, for they are very difficult to section and are almost impossible to draw.

During the day, the mites pass their time in these caverns. If disturbed, they come out with every appearance of irritation and run about with extraordinary quickness, or, as Lundstrom says, with "unglaublicher Schnelligkeit." They are strictly nocturnal, like so many other beasts of prey, and object to being exhibited in daylight.

As the summer goes on, they seem to get more and more numerous, and they are especially abundant in September; but when the leaves begin to dry up, and the little hairs which guard the entrances of their shelters shrivel away, some of the mites abandon the leaves altogether and appear to take refuge in crannies of the bark, in the bud-scales, often in the fruit, and sometimes even on the seed itself.

It has been found that, when such seeds are sown, the mites infect the seedling leaves as soon as these are sufficiently mature.

I am by no means sure that all the mites abandon the leaves before the latter fall in autumn. I suspect that many winter in leaf-mould, but only a skilled entomologist could decide such questions. On the bramble in spring I have found mites still active on last year's leaves when the new leaves were just ready to be infected. I have also found them in the lenticels of an oak and on the cut end of a pear twig. ${ }^{1}$

It is clear, however, that there is no difficulty about the succession of mites from year to year.

In the summer the number of these mites is extra-

1 These may not have been the mites which inhabit the leaves in summer.

TRANS. BOT, SOC. EDIN. VOL. XXIV. 
ordinary. It is difficult to realise this point until one has really tried to find them systematically.

I have myself observed them on the following plants, though not always in special acarodomatia. If there are appropriate nooks or crannies somewhere on the plant which are fit for shelters, the mites naturally make use of them. I ought to mention also that these were all the benignant mites, not, so far as I could judge, the sucking "red spiders":-

Anemone japonica, pæony, larkspur, aconite, a garden form of Thalictrum minus, Helleborus viridis, Liriodendron tulipiferum, common barberry, mahonia, Hypericum androscemum, H. calycinum, Gypsophila sp., Lychnis chalcedonica, Sidalcea malvaflora, common lime tree, ivyleaved geranium, Acer rubrum, common sycamore, $A$. campestre, horse-chestnut, holly, Dictomnus fraxinella. They are very common both on Leguminosæ and Rosaceæ. I found the following plants to be regularly inhabited, viz.:-Broom, Vicia cracca, bean, kidney bean, Lupinus mutabilis, Galega orientalis, Robinia pseudacacia, common laburnum, gooseberry, black currant (Phytoptus is not common at Newton), bramble, raspberry, loganberry, strawberry, common sloe, gean, cherry, Prunus padus, $P$. laurocerasus, P. lusitanicus, Spircea ulmaria, S. filipendula, S. aruncus, and three other species of Spiræa, Geum urbanum, Rosa canina, Cotoneaster frigidus, hawthorn, apple, pear, Pyrus aucuparia, P. fennica, Epilobium montanum, Deutzia crenata, Philadelphus sp., and Astilbe sp., Heracleum spondylium, Eryngium planifolium, ivy, Aucuba japonica, common elder, Viburnum opulus, honeysuckle, Valeriana pyrenaica, Cephalaria tartarica, Echinops Ritro, Senecio vulgaris, Solidago virgaurea, Jerusalem artichoke, tansy, Aster corymbosus, Michaelmas daisy, and a tall garden variety of Achillea millefolium, Campanula carpatica, Lobelia cardinalis, Rhododendron ponticum, common azalea, Lysimachia vulgaris, Fraxinus elatior, F. ornus, lilac, privet, Forsythio viridissima, Gentiana asclepiadea, Veronica longifolia var., Antirrhinum majus, foxglove, Lamium maculatum, Monarda didyma, Polygonum virginicum, box, common nettle, Ulmus montanus, alder, hazel, birch, oak, beech, 
hornbeam, Salix caprea, Solomon's seal. They also oceur on the male fern, lady fern, and common bracken-that is, on about 113 species, mostly of herbaceous garden plants, and belonging to 44 natural orders. These were observed in the garden at Newton, near Dumfries (Kirkcudbrightshire), and at various places in Dumfriesshire.

This list is by no means the result of an exhaustive study of common British plants. I began by choosing plants at random, intending to obtain a percentage of British and cultivated forms which are regularly visited. But I have been so often deceived by not at first detecting the mites that I came to the conclusion that such a list would be misleading.

It is very difficult to be sure that any plant is free from them. No one would ever suppose that almost glaucous rain-shy plants like Gypsophila and Thalictrum were inhabited by them. Nor are they absent from either glossy leaves or very hairy leaves, as some have supposed.

It has been said by several authorities that acarodomatia only occur on dicotyledonous trees and shrubs. That is not, however, the case. They are very common on tall herbaceous plants, and even occur on quite lowly herbs, though this is unusual.

'True acarodomatia have been found on two species of Dioseorea in the Congo by de Wildemann (2), and Zimmermann (3) also speaks of mites on the under side of the leaves of Arundinaria japonica. That they occur on the common Solomon's seal, where I found them abundantly at the base of the stem leaves, is a very interesting point.

Another point that should perhaps be mentioned is that acarodomatia do not afford a clear proof of a warm, humid climate. Peola (4), in studying the fossil Tertiary flora of Piedmont, discovered well-marked acarodomatia on the leaves of Oreodaphne Heerii, Cinnamomum polymorphicum, and Laurus canariensis; but it can hardly be said that this in itself shows that the climate was warm and humid. There are plenty of acarodomatia not only in Britain but in the tropics.

It would be easy to give a list of those plants which have acarodomatia, but this is hardly necessary. The researches of Lundstrom, von Lagerheim (5), Malme (6), 
Loesener (7), Schumann (8), Ludwig (9), Magoczy-Dietz (10), Penzig and Chabrera (11), Guerin (12), Delpino (13), and Rocchetti (14) have shown that these shelters exist in the following natural orders, viz.: Melastomaceæ, Menispermaceæ, Euphorbiaceæ, Piperaceæ, Dipterocarpeæ, Thymeleæ, Styracaceæ, Simarubeæ, and especially in Lauraceæ and Rubiacee. The last-mentioned author has a list of 270 acarophilous species.

Moreover, many plants which are regularly visited or inhabited by mites are without anything that one can call an acarodomatium. The mites take up residence in any convenient nook or cranny, and one cannot say that these crevices are specially produced for the good of the mites.

Thus many forest trees have holes in the trunk where some branch has decayed away, and birds such as the titmouse nest in holes of this kind. Titmice are very useful to the trees, and find these hollows very convenient, but the holes were not formed for the good of the titmouse, although this bird is one of the most useful of British species.

When one reflects on the multitude of mites visiting regularly so many plants, it is impossible not to speculate as to what is their part in the general economy of plant life.

Lundstrom suggested that they kept the leaves free of dangerous fungi and insects.

It is well known that in tropical and subtropical countries many plants are subject to the attacks of leaf-epiphytes. It is quite common to find leaves entirely covered by a heterogeneous vegetation of algæ, lichens, mosses, and liverworts. Stahl has figured the leaf of a Medinilla so overgrown by an epiphytic vegetation of this kind that it must have been impossible for it to carry on its functions. Such leaf-epiphytes are exceedingly common in many vegetation formations in the tropics.

Now, most of Lundstrom's mite-plants belong to certain districts in South America. Malme some time afterwards visited the same locality. He found that in these light woods known as "Capoes" smooth-leaved shrubs were infested with these epiphytes, but that the acarophilous plants with acarodomatia were much less or not at all affected. Penzig and Chabrera confirm this observation. 
Even in this country it is unusual to find either "red spider" or "Phytoptus" on the same leaf as the benignant mites. I have never myself seen them together, and very seldom seen aphides accompanying the true mites.

Certain observations which have been made on the habits of the benignant mites are of great importance.

Their mouths are not adapted for sucking the sap of plants, but for chewing or biting (Aurivillius (15)). Lundstrom himself saw fungus spores between the mouth parts of living acarids. Spores and fragments of fungus hyphæ have been found in their shelters. Dr. Aurelio de Gasparis caught Tydeus foliorum in the act of piercing an insect's egg.

According to Banks (16), Tydeus gloveri eats the eggs and young of scale insects, and both Rhyncholophus and Cheyletus are also said to prey on scale insects. Cheyletus also eats the eggs of a cicada, and certain Gamarid mites live on minute plants, bacteria, small fungi, etc.

These observations seem almost to prove the truth of Lundstrom's suggestion. It would be interesting to try if these mites could not be utilised to keep down "mussel scale" and similar pests in greenhouses.

These mites, therefore, may be regarded as an active and numerous police, keeping in check all sorts of fungus and insect pests which might otherwise do serious harm.

But there is another possibility which, to my mind, is of even more importance.

The atmosphere is, in its lower layers, crowded with enormous quantities of motes or dust-particles. They are of the most diverse origin. Of the inorganic dust-particles some did not belong to our earth originally, but formed part of a falling star or perhaps a comet's tail. Other particles have been thrown out in volcanic eruptions. The dust from Krakatoa, for instance, is said to have been reflected out and back again, and to have passed right round the world three or four times.

Fine dust from the Sahara and other deserts probably travels great distances. I have seen quantities of it on a steamer's deck quite a long way from shore. Mr. John Aitken (17), in one of his classical papers on this subject, describes how dust-particles from the densely inhabited 
districts of France and Belgium seemed to have been caught up in a cyclone, carried right round by the north of Scotland, and reached his instruments at Kingairloch (28 miles from Ben Nevis) with a north-westerly wind.

These inorganic dust-particles must, therefore, be miscellaneous; they probably differ both in chemical constitution and in physical character, though they are all exceedingly minute.

But the organic part of the dust-particles is perhaps even more interesting.

It is hardly necessary to say much about the enormous number of germs, spores, pollen grains, and other organic material which seems usually to hover in the atmosphere.

Dust-like seeds are characteristic of many phanerogams, and especially, according to Ridley, of many of those which have colonised oceanic islands. Fern-spores also must be abundant in the atmosphere. I need hardly recall the classic case of Krakatoa, for, even in this country, many kinds of ferns and even some flowering plants establish themselves on trunks of trees, bridges, and walls, sometimes miles away from their nearest neighbour.

With mosses and lichens, the facts of their distribution both in the Arctic and Antarctic and on mountain summits are very remarkable. Fink (18) discovered no less than thirty forms of lichen on a wall that had only been built thirty years. One should also mention, perhaps, the trades dust which falls in the Atlantic, and which consists of an alga, Trichodesma Hildenbrandtii forma atlantica, the regular distribution of yeast-cells on fruits, Dietel's experiments which showed that spores of rust-fungi could always be detected on plates left exposed during the summer.

Many other instances could be mentioned, but this hardly seems necessary. One of the most recent papers, however, can hardly be omitted in this connection.

Galeotti and Levi (19) studied the distribution of bacteria and fungus spores on the snow of high Alpine summits. From a cubic centimetre of water melted from the snow found on Point Strahling, at an altitude of 3116 metres, they obtained 147 colonies of bacteria and 20 colonies of Hyphomycete fungi. In one case (Lyskamm) they found only one colony of Hyphomycetes; yet on another summit 
(4560 metres), Gnifetti, there were no less than 40 bacterial and 3 fungus colonies from a cubic centimetre of melted snow.

However much allowance may be made for the share taken in the transport of spores by insects and birds, these instances are enough to show that even at altitudes of 13,000 feet the air contains living spores in great abundance.

When rain falls, a very large proportion of the floating dust-particles is washed out of the air and falls upon the foliage of plants. When the drops reach the leaves, the water is carried down to the petioles and stems by a series of grooves and gutters or flat surfaces which differ almost in every particular type of leaf.

These ingenious contrivances for carrying off rain-water are much too complicated to describe, but the result is to deposit all dust contained in the rain on certain well-defined lodging-places, usually about the base of the lamina or of the petiole.

I examined this dust microscopically, collecting it from about 26 species of plants. The results were too monotonous for it to seem worth while to go further into this side of the question.

In every case I found such easily recognised objects as lichen soredia, spores of rust-fungi, algal cells, pollen, yeast cells; in every case bacteria were to be seen. The proportion of these organic particles seemed to me extraordinarily high, at least in all cases when the leaf was more than 18 inches above the ground.

The point which most impressed me was the extraordinarily high manurial value of this plant-dust.

Not only does the inorganic part consist of very fine particles of the most varied mineral character, but the organic part not only forms a large proportion of the dust, but consists mainly of spores, etc., which must contain the most concentrated nutritive material.

Not only so, but there are grazing animals, the mites, to devour this combined nitrogenous matter, and, as I have pointed out, bacteria are available to break up and transform the waste products.

If this material, when dissolved in rain-water, enters 
the leaves, then it seems that a whole series of complex adaptations have been prepared to utilise all this rich air-food.

But here I am on very delicate and dangerous ground. Is it possible for rain-water with dissolved salts to enter the leaf?

That question has been debated, often with great violence, for something like 179 years. Naturally, I do not wish to dogmatise on this difficult point. But several of the best authorities on vegetable physiology admit that such absorption does take place. Both Sachs and apparently Vines agree that this is possible. Pfeffer remarks as follows: "Dem Gemäss können sehr wohl kleine Quantitäten von gelösten Stoffen mit Regen und Thautropfen in die Blätter gelangen." I do not find Kny's (21) experiments in the least conclusive. They have been often quoted as showing that no such absorption takes place, but the following extract seems to me to show that such absorption can take place even under very heroic treatment: "Die in Oel steckenden besprengten Zeigten beginn des Welken; die in Oel steckenden nicht besprengten waren stark welk." Neither Liebig nor indeed anyone supposes that such absorption can be large in amount. It is probably only a very minute proportion of the water that enters by the roots.

Nevertheless, when one remembers the rich manurial value of this dust, that it is carefully strained out of the rain by a whole series of elaborate contrivances, and also that there are neat arrangements for encouraging mites to reside permanently on the leaves, one can only draw the conclusion that mites, bacteria, and rain-gutters in the leaves form together one of the most interesting cases of symbiosis that has yet been discovered.

\section{AUTHORITIES.}

(1) Lundstrom.-Acta Nova Upsal., ser. 3, xiii., 1886-1887 ; Bot. Centralblatt, 1886, p. 282, and 1890, p. 246.

(2) De Wildemann.-Com. Rend., 1904, pp. 551 and 913.

(3) Zimmermann.-Ann. Jard. B. Buitenzorg, xvii., 1900-1.

(4) Peola. - B. Soc. Geol. Ital, xxiii., 1904.

(5) Von Lagerheim.- Bot. Centralblatt, 1892, p. 238.

(6) Madme.-Svenska Vet. Akad. Handl., Bd. xxv., 1900.

(7) Loesener. - Biolog. Centralblatt, Bd. xiii., 1893.

(8) Schumann. - Pringsheim, Jahrbuch, xix., 1888.

(9) Ludwig._-Biologie d. Pflanzen, 1888. 
(10) Magoczy-Dietz.-Bot. Centralblatt, xliii., 1891, p. 393.

(11) Penzig and Chabrera.-Malpighia, anno xvii., 1903.

(12) Guerin.-B. S. Botan. de la France, tom. liii., 1906.

(13) Delpino.-B. S. Bot. Ital., x., 1901.

(14) Roccherti.-Contrib. Biol. Veg., iv., 1905.

(15) Aurivillius.-Acta Nova Upsal., ser. 3, xiii., 1886-87.

(16) Banks.--Proc. U.S. Nat. Mus., xxviii., 1905.

(17) Aitken.-Trans. R.S. Edin., xxxvii., pt. 3, 1894.

(18) Fink.-Bot. Gazette, xxxviii., 1904.

(19) GaLeotri and Levi.--Arch. Ital. de Biol., tom. liii., 1909.

(20) Pfaffer. - Pflanz. Physiologie, Leipzig, 1897.

(21) KNy.-Ber. d.d. Bot. Ges., Bd. iv., 1886.

On Some British Hybrid Roses. By J. R. Matthews. (Plate XII.)

Although within recent years considerable attention has been given to the genus $R o s a$, much still remains to be done in way of systematic classification. This is perhaps more true of the section of Pimpinellifolice hybrids than of any other section of the genus. The difficulty obviously arises from the hybrid origin of these roses; and until their exact parentage is known, it seems to me impossible to expect a satisfactory classification of the individual species which go to form the three groups of the section. Especially is this true of the group Pimpinellifoliæ $\times$ Villosæ, where too much stress has been laid on technical characters, such as size and serration of leaflets, glandularity, hairiness, etc., and little or no reference has been made to the characters of the possible parents.

The position of the sepals appears to be a very important consideration, but the determination of this point is frequently rendered difficult owing to the fact that in most of these hybrids the fruit aborts before the real position of the sepals can be ascertained. But if this matter could be determined from observation of the living plants (herbarium specimens are not always to be depended upon), a great advance would be made in determining the second parent, and, as a consequence, the classification of the species would be rendered easier and, at the same time, more natural.

It is not my intention to give a detailed description of all the hybrid roses that have been found in Britain. That 